\title{
Scientists must act on our own warnings to humanity
}

\author{
Charlie J. Gardner ${ }^{1 *}$ and Claire F.R. Wordley ${ }^{2 *}$ \\ ${ }^{1}$ Durrell Institute of Conservation and Ecology, University of Kent, Canterbury CT2 7NR, UK \\ ${ }^{2}$ Department of Zoology, University of Cambridge, Cambridge, CB2 3QZ, UK
}

Corresponding author: cg399@kent.ac.uk. Tel: 0044 (0)1227 816762

* These authors contributed equally to this work

Word count: 1079 
We face interconnected planetary emergencies threatening our climate and ecosystems.

Charlie J. Gardner and Claire F.R. Wordley argue that scientists should join civil disobedience movements to fight these unprecedented crises.

Under current business as usual pathways, global heating will cause a temperature increase of 2$4.9^{\circ} \mathrm{C}$ by 2100 (Raftery, A. E. et al. Nat. Clim. Change 7, 637-641; 2017), and a simultaneous ecological crisis threatens the extinction of a million species over the next few decades (Díaz, S. et al. IPBES; 2019). We face the complete loss of sea ice, tropical rainforests, and coral reefs, and will suffer heatwaves, droughts, and storms that may render much of the planet uninhabitable and cause devastating human suffering and conflict.

Scientists have worked hard to communicate the severity of these crises - to each other through peer-reviewed publications, but also to policymakers and the wider public. On two occasions we have collectively issued stark 'warnings to humanity'; in 1992 when the Union of Concerned Scientists warned that "a great change in our stewardship of the earth and the life on it is required, if vast human misery is to be avoided and our global home on this planet is not to be irretrievably mutilated" (Union of Concerned Scientists; 1992), and again in 2017 with over 15,000 signatories (Ripple, W.J. et al. BioScience 67, 1026-1028; 2017).

Beyond our day jobs, many scientists have also tried to influence policy through available political and economic channels - we have voted in elections, written letters and emails, donated to advocacy groups, and marched in the streets. Many of us have also tried to reduce our 
personal use of the Earth's resources. However, none of these efforts have worked at the necessary scale. It is time for a new approach.

Non-violent civil disobedience - the active refusal of a citizen to obey certain laws, orders, or commands of a government or occupying power - is demonstrably effective at initiating political change. Many of the most profound political and social changes of the last century were brought about in this way, and leading practitioners, such as Rosa Parks, Emmeline Pankhurst, Martin Luther King, and Mohandas Ghandi, once reviled as dangerous dissenters, are today revered as heroes. Moreover, civil disobedience requires relatively few people to be effective, with sustained action by $3.5 \%$ of the population sufficient even to topple dictatorial regimes (Chenoweth, E. \& Stephan, M.J. Why Civil Resistance Works: The Strategic Logic of Nonviolent Conflict. Columbia University Press; 2012).

There is now a growing tide of people embracing civil disobedience to protest against the planetary emergencies we face, from the Sunrise Movement in the USA and Ende Gelände in Germany to the Greta Thunberg-inspired global School Strike for Climate. Perhaps the most notable example is Extinction Rebellion. In April 2019, Extinction Rebellion activists blockaded four sites in central London for 11 days, alongside related actions in 80 cities across 33 countries. The London actions constituted the largest act of civil disobedience in modern British history and led to over 1,100 arrests, helping achieve the highest ever levels of UK news coverage on the climate crisis. The environment has since risen rapidly to become the third most important issue for British voters (YouGov https://yougov.co.uk/topics/politics/articlesreports/2019/06/05/concern-environment-record-highs; 2019). 
It is too early to ascertain the effects of these actions on policy. However, the UK Parliament, along with the Scottish Parliament, the National Assembly for Wales, the Oireachtas (Irish Parliament) and (as of mid-July 2019) 799 local councils in 17 countries have now declared a Climate Emergency. Many have also attributed the record number of Green Party MEPs elected in the 2019 European elections to the Extinction Rebellion actions and school strikes.

As conservation scientists and members of Extinction Rebellion, we encourage our fellow scientists to join us in embracing activism. In April 2019, over 12,000 scientists signed a letter endorsing the global school strikes, which are acts of civil disobedience, and praising the movement as "justified and supported by the best available science" (Hagedorn, G. et al. Science 364, 139-140; 2019). We ask that scientists take this one step further, and themselves join civil disobedience movements.

This does not mean that all scientists must commit acts of civil disobedience - some have more privilege to risk arrest than others. But we can all use our professional skills to support these movements. We can give talks, act as media spokespeople, write or speak publicly about why we have embraced civil disobedience, or support organisational tasks. However, for those who can, committing civil disobedience sends a powerful message about how seriously scientists treat these crises. For example, Professor Lynne Quarmby and Dr Alejandro Frid were arrested blocking coal trains in Canada, and Professor James Hansen has been arrested multiple times for protesting against fossil fuel infrastructure. Moreover, our involvement in popular environmental movements can boost their credibility, change the tone of media reporting, and ensure all 
members of civil disobedience groups are well versed in climate science, ecology, and other relevant disciplines.

Some may argue that advocating for a political position jeopardises our scientific credibility. However, experiments have shown that making advocacy statements did not affect the perceived credibility of scientists (Kotcher, J.E. et al. Environ. Commun. 11, 415-429; 2017). While scientist participation in the 2017 March for Science events in the United States slightly altered the 'Scientist Feeling Thermometer' (a small rise in positive feeling from liberals and a small decline for conservatives), it had no effect on how much people trusted scientific research (Motta, M. PS Polit. Sci. Polit. 51, 782-788; 2018).

Others may argue that scientists should not take part in civil disobedience because it bypasses the 'proper channels' for political influence. However, lobbyists for fossil fuel corporations benefit from much greater access to political processes than is available to scientists or environmental campaigners. For example, in 2018 the fossil fuel industry spent over US $\$ 125$ million lobbying politicians in the United States alone (OpenSecrets.org https://www.opensecrets.org/lobby/indusclient.php?id=E01\&year=2018;2019). Fossil fuel corporations have invested heavily in misinformation and an anti-science agenda with the express purpose of delaying action on climate change; alongside complicit governments, they have convinced the world to carry on as normal.

But we can no longer carry on as normal. 'Acceptable' forms of influence are not working, and we are running out of time - people in countries such as India and Mozambique are already 
suffering from climate breakdown. The scientists who alerted the world to the climate and ecological crises have a moral duty to join the popular movements demanding political action.

\section{Acknowledgements}

We thank Dr Laura Kehoe for comments on the manuscript.

\section{Author contributions}

CJG conceived the paper, CJG and CFRW wrote the paper.

\section{Competing interest declaration}

Both authors are members of Extinction Rebellion but receive no financial or other benefits as a result of publication. 